culture ministry replaced the existing international scientific committee - which was peppered with government officials, including Lascaux management — with a smaller one made up exclusively of scientists. Giving the committee greater scope to offer independent scientific advice was one of UNESCO's key demands.

Michel Goldberg, a biologist at the Pasteur Institute in Paris and a fierce critic of recent conservation efforts at Lascaux, says he's generally pleased that the new board contains many more researchers from the hard sciences and fewer from the art world, although he bemoans its lack of experts in key areas such as subterranean climate or mycology. Also positive, he says, is that Mauriac seems to be postponing new work until the incoming board has had its say. "The current administration seems much more careful and less interventionist," he notes.

But board member Robert Koestler, director of the Smithsonian Institution's Museum Conservation Institute in Suitland, Maryland, complains that his repeated requests for access to existing research data on the cave, and to be able to invite outside experts, have been met with stonewalling. "All we get are reports and presentations on the ecology, hydrology and three-dimensional modelling of the climatology of the cave," says Koestler. "But we don't have the data."

Yves Coppens, a palaeoanthropologist at the Collège de France in Paris who chairs the board, assured Nature that members' requests for outside experts and data will be fulfilled in coming meetings. The initial meetings were intended to be introductory, he says.

The immediate problem the board must tackle is the black fungus. Few areas of the paintings have been affected so far, according to Mauriac, who adds that the fungus currently seems to be stable in some parts of the cave and receding in others. But it could ultimately do more damage than previous infestations, because it stains the walls with melanin, and the stains remain even if the fungi are killed.

Researchers have yet to identify the fungus, with two laboratories putting forward different candidates, one a Ulocladium species and the other Scolecobasidium. Nor have they decided on the best way to kill it, although fungal enzymes that attack black fungi are a potential solution. Tackling the melanin stains on the rock art will also be difficult, as aggressive treatments are ruled out.

The broader challenge, say scientists, will be to understand the workings of the cave well enough to stabilize its subterranean environment and stave off any future microbial attacks.

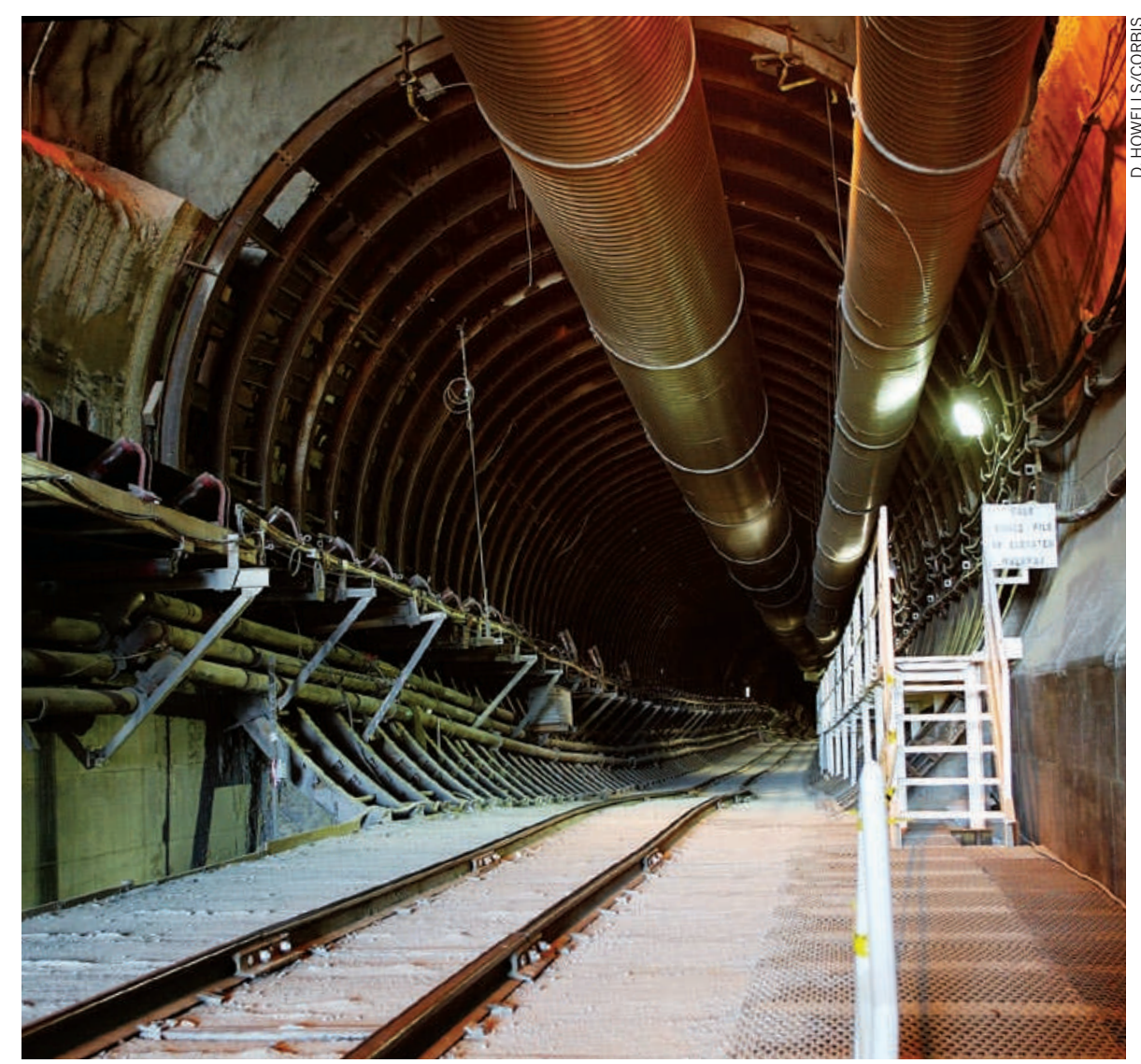

The US government wants to reverse plans to store nuclear waste at Yucca Mountain.

ENERGY

\title{
Fuel and waste no bar to US nuclear growth
}

\section{Report finds that plentiful fuel supplies and temporary storage will buy decades of time to develop a longer-term strategy.}

\section{BY JEFF TOLLEFSON}

$\mathrm{W}$ hat will it take to spark a nuclear renaissance in the United States? Recognizing that nuclear power could play a much greater part in the future of the country's energy production - a shift some advocates say will be unavoidable to reduce dependence on fossil fuels - President Barack Obama's administration has been working to reshape key aspects of US nuclear policy. Now, an analysis led by the Massachusetts Institute of Technology (MIT) in Cambridge offers guidance on some of the thorniest questions surrounding the fuel and waste side of the nuclear equation.

The report arrives as the Department of Energy (DOE), making good on one of Obama's campaign promises, seeks to withdraw a decades-in-the-making application for a nuclear- waste repository beneath Yucca Mountain in Nevada. Although the department is motivated by long-standing opposition to the repository by state and environmental groups, its right to withdraw its own congressionally mandated application is currently under review by the US Nuclear Regulatory Commission.

The MIT report steers clear of the politcal debate and says there is ample time to resolve the fate of spent nuclear fuel piling up at the nation's 104 existing nuclear reactors. In fact, it says, the United States could plan to keep spent reactor fuel in interim storage for up to a century, while developing an adequate geological solution for long-term storage. This would allow the radioactive waste to cool, making it easier to manage and store permanently, and would preserve the option of reusing it as fuel should technologies advance. This would also be more palatable to the public, the report 
suggests, because the stored waste would be accessible and actively monitored.

"We need to recognize that we have choices," says Ernie Moniz, director of the MIT Energy Initiative and co-chair of the study, 'The Future of the Nuclear Fuel Cycle', which was released on 16 September. Moniz, along with several members of the report's advisory committee, is also part of the Blue Ribbon Commission on America's Nuclear Future, which was formed by the DOE in January to "conduct a comprehensive review of policies for managing the back end of the nuclear fuel cycle". The MIT report could be read as a preview of what the government might be presented with when the commission reports its interim findings next year.

The report also squares well with another of Obama's decisions: to de-emphasize a proposal from the administration of former president George W. Bush to supplement limited uranium supplies by accelerating plans to reprocess spent fuel. Reprocessing is controversial because it concentrates plutonium and uranium isotopes that can be used in nuclear weapons. Taking into account past trends and future projections for uranium extraction, the report suggests that enough is now available to obviate the need for reprocessing for decades to come.

Advanced reactors, including those that work on repro-

The economics of nuclear energy could change substantially if and when the United States moves to curb carbon dioxide emissions.

cessed fuel, could become an option in several decades' time, the report says. But, it adds, to ensure that the best choices are made further down the road, the United States must maintain a viable research programme - investing around US $\$ 1$ billion per year - into the full suite of nuclear technologies.

Even so, reactors using current technology will continue to produce most of the nation's nuclear power through to 2100 (see 'A slow burn'). In an effort to better understand the performance of conventional reactors, the DOE said that one of three new Energy Innovation Hubs announced last year will concentrate on developing computer simulations that can reproduce conditions inside existing reactors, and test strategies for improving safety and extending reactor lifespan. Congress baulked

\section{A SLOW BURN}

In the United States, energy production by conventional reactors is predicted to surpass that by advanced new-technology reactors for at least a century.

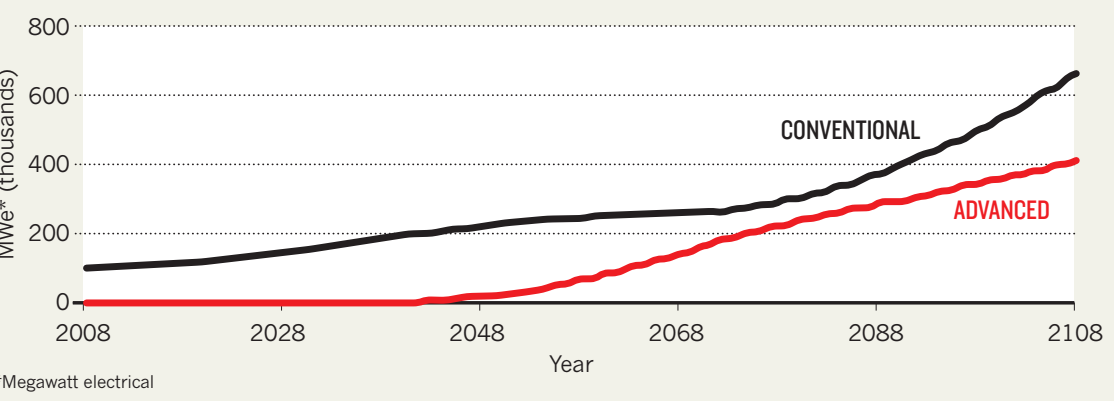

at the idea of developing an expensive reprocessing programme under Bush, but it seems to support Obama's approach. Although lawmakers have yet to approve the DOE's fiscal 2011 budget, which includes $\$ 824$ million for nuclear energy, legislation currently moving through Congress largely endorses the administration's nuclear agenda. The House Science and Technology Committee is expected to vote on a comprehensive bill this week, and similar legislation is moving through the Senate.

Thomas Cochran, a senior scientist in the Natural Resources Defense Council's nuclear programme in Washington DC, gives the administration credit for backing off from nuclear reprocessing, but says that the research programme is still too focused on futuristic fuel cycles. He agrees with the MIT study that uranium will remain abundant and cheap, and adds that this is all the more reason to concentrate on research that could make conventional nuclear reactors cheaper and more efficient. "The priority is misplaced," Cochran says. "They should be doing basic science that can help reduce costs."

Its high cost relative to fossil fuels, as well as financial risk, remain impediments to nuclear expansion in the United States. To help the industry to overcome economic barriers, the DOE is seeking $\$ 36$ billion in new loan guarantees in addition to the $\$ 18.5$ billion it has already secured. But many fear that the government is doing too much for what is, in principle, a mature industry. The current subsidies, Moniz says, go well beyond what he and his colleagues recommended in their first nuclear study in 2003.

Although some nuclear plants will probably be built in the coming years, the pace of development looks set to be much slower than some predicted just a few years ago. In March, the Exelon Corporation, based in Chicago, Illinois, and the operator of the largest collection of nuclear plants in the United States, backed off from plans to build a new nuclear plant in Texas, in part because it expects natural-gas prices to remain low, making nuclear energy less competitive. The falling demand for electricity during the recession and a long-term trend towards smaller generating stations, which can be easily powered by natural gas, have further dampened enthusiasm for new nuclear plants.

If nuclear generation does expand anywhere in the United States, it is most likely to begin in states with regulated markets, where it is easier for utilities to charge higher rates in order to recoup their costs. So says Marilyn Kray, vicepresident of nuclear project development at Exelon and president of NuStart Energy Development, a consortium organized to push the first new nuclear plants in decades through the regulatory process.

But the economics of nuclear energy could change substantially if and when the United States moves to curb carbon dioxide emissions. A cap-and-trade system would naturally give nuclear power an edge by making fossil-fuel generation more expensive. Indeed, Kray says, the market for low-carbon electricity is only going to grow in the decades to come, and companies such as Exelon may one day renew their applications to build reactors if the first round of plants is a success.

"Whether it constitutes a renaissance or not," Kray says, "I think either way you get new nuclear plants." - SEE COMMENT P.391

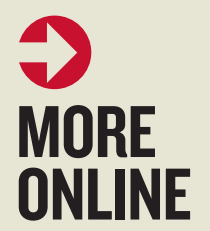

\section{LATEST STORIES}

- How stress shapes ecosystems go.nature.com/7JISZX

- Volcano borehole prompts safety doubts go.nature.com/eH4FEV

- Laser makes molecules super-cool go.nature.com/oBwNOm

- US stem-cell crisis go.nature.com/hL87IT

\section{JOIN THE CONVERSATION}

How will the Swedish election shake up research? go.nature.com/iYalte

"Sweden has produced way more PhDs than there are positions for. Now a person with a doctorate is competing with everyone in entry level positions." Chris McMahon

\section{NATURE VIDEOS}

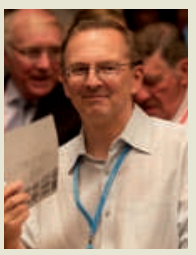

Nobel laureate Jack Szostak of Harvard Medical School in Boston talks about the handedness of life. go.nature.com/c4MmzJ 